\title{
SCHOOL PROBLEMS AND TEACHERS' COLLABORATION: BEFORE A COLLABORATIVE PROBLEM SOLVING PROGRAM
}

\author{
Alexandra Ataíde ${ }^{1}$, Isabel Souto ${ }^{2}, \&$ Anabela Pereira ${ }^{3}$ \\ ${ }^{1}$ Research Centre on Didactics and Technology in the Education of Trainers (CIDTFF), \\ University of Aveiro (Portugal) \\ ${ }^{2}$ Education and Psychology Department, University of Aveiro (Portugal) \\ ${ }^{1,3}$ Research Centre on Didactics and Technology in the Education of Trainers (CIDTFF), \\ University of Aveiro (Portugal)
}

\begin{abstract}
This study precedes a collaborative problem solving intervention program with teachers (teachers, educators and school direction board) to tackle together real and complex problems at school and to promote professional development. Therefore, the main objective is to acknowledge teachers' problems, needs and collaborative context at school. In the present study we sought to identify teachers' problems and needs and the main factors associated with the development of teachers' collaborative work. Specifically, we intent to understand which dimensions act as constraints to the development of collaborative work. Ultimately, we intend to contribute with scientific evidence in this field to allow the development of an effective teachers' collaborative problem solving program at schools. Therefore, an empirical study was carried out involving 153 teachers, working in preschool, elementary, middle and secondary schools in a city of Aveiro's region, in Portugal. To this assessment, the following instrument was used: a questionnaire developed by researchers aimed to collect information about teacher's collaborative practices, problems and needs. Our study points out to four main findings: i) the main problems at school identified by teachers are teachers' work overload, physical and/or mental exhaustion, the high number of students per class, teachers' lack of motivation, students' lack of motivation and violence among students; ii) teachers' main needs are the reduction of the number of students per class, well-being and social intercourse activities, and peer support; iii) the efficacy of school direction board and teachers on school problem solving has positive significant correlation with teacher collaborative work; iv) the cumulative total of school problems identified by teachers has significant negative correlations with teachers' participation on collaborative work. The present study responds to the research gap in the analysis of the relation between school context problems identified by teachers and collaboration practices. Before beginning a collaborative problem solving program is essential that the researchers acknowledge teachers context and start with scientific data in order to set the best conditions to an efficient intervention.
\end{abstract}

Keywords: School problems, teacher collaboration, collaborative problem solving, teacher professional development, well-being in teaching.

\section{Introduction}

Work overload, bureaucracy, unstable working conditions, lack of recognition, lack of motivation and burnout are some of the main problems most teachers face nowadays in Portugal. Scientific studies reveal very demanding contexts in schools and underline them as priority and urgent challenges to tackle in education. According to the first survey in Portugal to more than 15,000 teachers, $75 \%$ have emotional exhaustion. In fact the preliminary report of this study reveals that $27.3 \%$ of teachers interviewed refer critical or extreme signs of emotional exhaustion. This survey revels also that $84 \%$ of teachers in service wish to retire (Azevedo, Veiga, \& Ribeiro, 2016; Patrão, Rita, \& Maroco, 2012; Varela et al., 2018; Veiga, 2013).

Teachers' workplace dissatisfaction and burnout are intrinsically related with teachers' absenteeism, low work investment, and ineffectiveness in supporting students' learning and development. Actually, inside and outside the classroom effects arise from teachers' lack of motivation, stress and emotional exhaustion. Nevertheless, when teachers believe in their personal and collective effectiveness to motivate and promote learning, they influence positively learning environments and the level of student progress. Therefore, educators need high levels of well-being, self-efficacy, and confidence. To develop answers to these problems is a top priority in schools and a political and public duty. Policymakers and schools are challenged to promote teachers' wellbeing, value recognition and feedback systems, which are linked to improved teaching practices (Bandura, 1993; Patrão, Pinto, \& Santos-Rita, 2012; Pereira, 2013; Schleicher, 2018; UNESCO, 2017). 
When schools have collaborative power among groups, the development of talent increases. Collaborative cultures create a sense of responsibility and proactivity. They are transformative and crucial for schools' agents to problem solving. Teachers who engage in collaborative activities apply more innovative pedagogies, reveal greater professional satisfaction and self-efficacy (Andy Hargreaves \& Fullan, 1998, 2012; OECD, 2014; Schleicher, 2018). One of the biggests challenges nowadays is to find out ways to teachers to build a common ground, set together challenges to tackle and collaborate more deeply to achieve greater impact. In turn, teachers train students more effectively in developing collaboration, and other skills, when they practice what they preach (Coke, 2005; Andrew Hargreaves \& Fullan, 2013). Thereby, more opportunities should be created for teachers to collaborate and to solve real and complex problems together. A human-centered, structured and collaborative problem solving (CPS) approach promotes innovative and effective responses to current educational challenges. It is a priority to train teachers in CPS and empower these educational leaders and changemakers (Fullan \& Hargreaves, 1991; Graesser et al., 2018; IDEO \& Riverdale Country School, 2012; Jardim \& Pereira, 2016).

\section{Objectives}

Our purpose in this article is to identify teachers' problems and needs at school and the main factors associated with the development of teachers' collaborative work. Specifically, we intent to understand which dimensions, problems and needs that cross teachers' work are constraints to the development of collaborative work. Ultimately, we intend to provide scientific evidence in this field and to allow the development of an effective teachers' collaborative problem solving program at schools.

\section{Method}

An empirical study was carried out involving 153 teachers, working in preschool, elementary, middle and secondary schools in a city of Aveiro's region. To this assessment, the following instrument was used: a questionnaire developed by researchers aimed to collect information about teacher's collaborative practices, problems and needs (Coutinho, 2014).

\subsection{Participants}

An empirical study was carried out involving 153 teachers. The sample comprise 26 males and 122 females (5 respondents didn't state gender), aged 38 to 63 years old $(\mathrm{M}=49,99 ; \mathrm{SD}=11,012)$. Teachers worked at an Aveiro group of schools in various levels of education, namely at nursery school/preschool $(n=19)$, elementary school/primary schools $(n=40)$ and middle and secondary school $(n=69)$. The sample also comprises participants that work in other functions as special education/psychology $(n=12)$, and 13 participants gave no information about the level of education taught. All the sample work characteristics can be seen in Table 01.

Table 1. Work characteristics of participants.

\begin{tabular}{llcccc}
\hline \hline Items & & \multicolumn{2}{c}{$\begin{array}{c}\text { Female } \\
(\mathbf{N = 1 2 2})\end{array}$} & \multicolumn{2}{c}{$\begin{array}{c}\text { Male } \\
(\mathbf{N = 2 6})\end{array}$} \\
& & $\mathbf{N}$ & \% & N & \% \\
\hline \hline Function & No information & 4 & 2,6 & 26 & 17,3 \\
& Preschool Educator & 12 & 7,8 & - & - \\
& Full professor & 104 & 68,0 & 20 & 13,3 \\
& Management / Direction / Other Positions & 2 & 1,3 & 4 & 2,7 \\
\hline Levels of & No information & - & - & - & - \\
education taught & Nursery school / Preschool & 18 & 11,8 & 1 & 0,7 \\
& Elementary school / Primary schools & 31 & 20,3 & 8 & 5,3 \\
& Specific subjects of middle and secondary school & 53 & 34,6 & 15 & 10,0 \\
& Other (Special education / Psychology / etc.) & 11 & 7,2 & 1 & 0,7 \\
\hline Type of Contract & No information & - & - & - & - \\
& Hired (temporary) & 13 & 8,5 & 6 & 4,0 \\
& Full professor (permanent) & 106 & 69,2 & 20 & 13,4 \\
\hline Work years & No information & - & - & - & - \\
& 0 to 10 & 1 & 0,7 & 2 & 1,3 \\
& 11 to 20 & 14 & 9,2 & 7 & 4,7 \\
& 21 to 30 & 63 & 41,2 & 9 & 6,0 \\
& 31 to 40 & 38 & 24,8 & 7 & 4,7 \\
& 41 to 50 & 1 & 0,7 & 1 & 0,7 \\
\hline \hline
\end{tabular}




\subsection{Instruments}

A teachers needs' assessment questionnaire developed by researchers was applied and aimed to collect information about: 1) Problems at the school context (excessive number of classes, lack of motivation, overload, absenteeism, poor interpersonal relations, reduced sharing, conflict, ineffective communication with parents, violence among students, stress and malaise environment, exhaustion, or others); 2) Needs (reduction of class numbers, co-worker support, vocational training, reduction in the number of students per class, welfare and coexistence activities); 3) Frequency and type of peer-to-peer collaborative work development (joint lessons, joint work involvement with different classes, collaborative professional learning, preparation of tests or activities); 4) Participation in collaborative work (to solve school problems); 5) Training of students to collaborative problem solving at school.

A teachers' sociodemographic questionnaire was applied aimed to collect Demographic characteristics (age, gender), as well informational issues and specificities of the work (function, level of education taught, work years, type of contract).

\subsection{Procedures}

Data collection in 2019 January, after obtaining the authorization from the school board. The distribution of the research protocol questionnaires was made on paper after holding project presentation sessions (three in total). At the same time, the demographic questionnaire was applied. All participants were informed of the objectives and voluntary nature of participation, as well as subsequent use of the data collected through informed consent, respecting the ethical and deontological principles inherent in the development of an investigation.

\subsection{Data analysis}

All analyses were done using IBM SPSS Statistics® (version 25). Descriptive statistics were assessed, as well as Several Pearson's correlate analyses were conducted to assess the relation between total school context problems and identified needs relationship with collaborative work development and participation.

\section{Results}

Concerning the total number of problems identified in the school context, results show that most of total respondents identified an average of 5 problems $(\mathrm{M}=5.31, \mathrm{SD}=3.52)$. Teachers' overload is pointed out as the main problem in the school context with $78,4 \%$ of the responder's votes (Table 2). When teachers were asked about other problems in school (besides the options), the high bureaucracy and administrative work was pointed out. In relation to the total number of work-related needs, results show that most of total respondents identify between 0 to $5(\mathrm{M}=1.71 ; \mathrm{SD}=1.069)$. Students per class reduction is pointed out as the main need with $52,3 \%$ of the votes (Table 2 ). When asked about other needs (besides the options), the reduction of bureaucracy and administrative work was reported. Regarding the results of collaborative work, $91.5 \%$ of professors affirms to participation in collaborative work, being pointed out that this is mostly provided through preparation of exams $(62,1 \%)$, and activities evolvement $(60,1 \%$; Table 2). It has been reported that collaborative work is provided mostly weekly, in all modalities. Interdisciplinary activities are pointed as other forms of participation in collaborative work.

Table 2. Work characteristics of participants.

\begin{tabular}{|c|c|c|c|}
\hline Items & & $\overline{\mathbf{N}}$ & $\%$ \\
\hline \multirow{10}{*}{$\begin{array}{l}\text { Problems identified in the } \\
\text { school context }\end{array}$} & Teachers' Overload & 120 & $\overline{78,4}$ \\
\hline & Exhaustion of teachers & 94 & 61,4 \\
\hline & Teachers' Lack of Motivation & 84 & 54,9 \\
\hline & Excessive number of students & 79 & 51,6 \\
\hline & Students' Lack of Motivation & 57 & 37,3 \\
\hline & Violence between students & 53 & 34,6 \\
\hline & Ineffective communication with parents & 36 & 23,5 \\
\hline & Low peer collaboration a & 34 & 22,2 \\
\hline & Superficial interpersonal relationships & 31 & 20,3 \\
\hline & Stress and malaise environment & 29 & 19 \\
\hline \multirow{6}{*}{$\begin{array}{l}\text { Needs identified in the } \\
\text { school context }\end{array}$} & Students per class reduction & 80 & 52,3 \\
\hline & Reduction in Classes & 56 & 36,6 \\
\hline & Wellness and social activities & 44 & 28,8 \\
\hline & Work colleague support & 33 & 21,6 \\
\hline & Support needs (other) & 30 & 19,6 \\
\hline & Professional qualification & 15 & 9,8 \\
\hline \multirow{6}{*}{$\begin{array}{l}\text { Collaborative work } \\
\text { participation }\end{array}$} & Preparation of exams & 95 & 62,1 \\
\hline & Activities involvement & 92 & 60,1 \\
\hline & Joint classes & 35 & 22,9 \\
\hline & Professional Learning & 35 & 22,9 \\
\hline & Others & 25 & 16,3 \\
\hline & Observation and feedback & 14 & 9,2 \\
\hline
\end{tabular}

a. Reduced collaboration between teachers (as a big team) 
Large percentage of participants claim to participate in collaborative activities so that together they can solve school problems $(n=109 ; 71.2 \%)$, mostly through teachers' assembly $(n=24,15.7)$, teachers' informal meetings $(n=21,13,7 \%)$ and specific conflict resolution $(n=17,11.1 \%)$. Also, large percentage of participants refer to empowering students to solve problems at school $(n=117,76,5 \%)$. In the analysis of total school context problems and identified needs relationship with collaborative work development and participation, many positive and negative correlations were found (Table 3). Total school context problems is the domain with most significant negative correlations presented, and reduced collaboration between teachers (as a big team) as the most positive significant correlations (Table 3 ).

Table 3. Relations between of total school context problems and identified needs with collaborative work development and participation.

\begin{tabular}{llccc}
\hline \hline & & $\begin{array}{c}\text { Total school } \\
\text { context problems }\end{array}$ & $\begin{array}{c}\text { Low peer } \\
\text { collaboration }\end{array}$ & $\begin{array}{c}\text { Total identified } \\
\text { need }\end{array}$ \\
\hline \hline Collaborative & Total & $\mathbf{- , 2 5 6 * *}$ & $-0,078$ & $-0,105$ \\
werk & Preparation of exams & 0,108 & $\mathbf{7 6 8 * *}$ & $\mathbf{, 2 0 4}^{*}$ \\
& Activities involvement & 0,067 & $\mathbf{, 7 3 7 * *}$ & 0,07 \\
& Joint classes & $-0,019$ & $\mathbf{, 9 5 4 * *}$ & $-0,063$ \\
& Professional Learning & 0 & b. & 0,196 \\
& Others & $-0,071$ & b. & $-0,029$ \\
\hline Collaborative work participation & $-0,163$ & b. & 0,179 \\
\hline $\begin{array}{l}\text { Empowering students to solve problems at } \\
\text { school }\end{array}$ & Observation and feedback &,$- \mathbf{1 7 9}$ & $-0,111$ & $\mathbf{- , 1 8 9 *}$ \\
\hline \hline
\end{tabular}

a. Reduced collaboration between teachers (as a big team)

b. It is not possible to calculate why at least one of the variables is constant

$* \rho<0.05 \quad * * \rho<0.01$

\section{Conclusion}

Nowadays teachers, students, parents and other educational agents face a demanding educational context in a time of constant change, global sustainability challenges and of technology advancing at an exponential rate and changing how we work and live. Problems are part of each educational community can be seen as challenges and as opportunities towards human-centered and collaborative problem solving approaches. Teachers as educational leaders need effective support to tackle exigent complex problems as work overload, burnout, high bureaucracy and administrative work, the high number of students per class, teachers' lack of motivation, students' lack of motivation and violence among students.

In this study there are evidences that teachers who identify more problems in school, participate less in collaborative activities and respondents who identify less problems report higher participation in collaborative work. Research studies reveal collaborative activities have positive influence in problem solving, well-being and job satisfaction. Nevertheless, the collaborative activities in which teachers participate are focused on routine tasks and work, such as preparation of tests or activities, joint lessons, joint work involvement with different classes, collaborative professional learning. Regarding to participation in collaborative activities to solve school problems, teachers mostly do it through teachers' assembly, informal meetings and specific conflict resolution. Most of them refer to empower students to solve problems at school. However this study evidences that teachers don't experience CPS approach, nor among teachers nor with students or other school agents (Graesser et al., 2018; Hattie, 2015; OECD, 2014, 2016; Schleicher, 2018). Our purpose in this study is to contribute to a CPS intervention program with teachers and to start sparking educational innovation. Finally we also intend to underline the importance of research and action to promote teachers' well-being, significant relationships in community and recognition as educational leaders.

\section{References}

Azevedo, J., Veiga, J. J., \& Ribeiro, D. (2016). As Preocupações e as Motivações dos Professores: Apresentação dos resultados de um inquérito. Centro de Estudos Sociais da Fundação Manuel Leão. Vila Nova de Gaia. Retrieved from http://www.fmleao.pt/wpcontent/uploads/2016/09/FML_PREOCUPACOES_MOTIVACOES_PROFESSORES_FINAL_ba ixa.pdf 
Bandura, A. (1993). Perceived Self-Efficacy in Cognitive Development and Functioning. Educational Psychologist, 28, 117-148. https://doi.org/http://dx.doi.org/10.1207/s15326985ep2802_3

Coke, P. K. (2005). Practicing What We Preach: An argument for cooperative learning opportunities for elementary and secondary educators. Education, 126, 392-398. Retrieved from https://eric.ed.gov/?id=EJ765674

Coutinho, C. P. (2014). Metodologia de Investigação em Ciências Sociais e Humanas - Teoria e prática. (S. A. Edições Almedina, Ed.). Coimbra. Retrieved from https://books.google.pt/books?hl=ptPT\&lr=\&id=uFmaAwAAQBAJ\&oi=fnd\&pg=PT3\&dq=related:PAeEiQ7bz0cJ:scholar.google.co $\mathrm{m} / \&$ ots=GgcI0u9SO3\&sig=A1SDf6r9ncWqIzlsYvkwa01MSlE\&redir_esc=y\#v=onepage\&q\&f=fal se

Fullan, M. G., \& Hargreaves, A. (1991). What's Worth Fighting For? Working together for your school. Ontario: The Regional Laboratory for Educational Improvement of the Northeast and Islands with the Ontario Public School Teachers' Federation. Retrieved from https://files.eric.ed.gov/fulltext/ED342128.pdf

Graesser, A. C., Fiore, S. M., Greiff, S., Andrews-Todd, J., Foltz, P. W., \& Hesse, F. W. (2018). Advancing the Science of Collaborative Problem Solving. Psychological Science in the Public Interest, 19(2), 59-92. https://doi.org/10.1177/1529100618808244

Hargreaves, Andrew, \& Fullan, M. (2013). The Power of Professional Capital: With an investment in collaboration, teachers become nation builders. JSD, 34(3), 36-39. Retrieved from http://www.michaelfullan.ca/wp-content/uploads/2013/08/JSD-Power-of-Professional-Capital.pdf

Hargreaves, Andy, \& Fullan, M. (1998). What's Worth Fighting for in Education? Open University Press.

Hargreaves, Andy, \& Fullan, M. (2012). Professional Capital: Transforming teaching in every school. (Taylor \& Francis LTD, Ed.). Routledge.

Hattie, J. (2015). What Works Best in Education: The Politics of Collaborative Expertise. London. Retrieved from https://www.pearson.com/content/dam/one-dot-com/one-dotcom/global/standalone/hattie/files/150526_ExpertiseWEB_V1.pdf

IDEO, \& Riverdale Country School. (2012). Design Thinking para Educadores. (Instituto Educadigital, Ed.) (1 $\quad$ edição). https://www.designthinkingforeducators.com/DT_Livro_COMPLETO_001a090.pdf

Jardim, J., \& Pereira, A. (2016). Perceived Impact of Lifelong Training in Teachers. Interacções, 12(42), 22-31. Retrieved from http://revistas.rcaap.pt/interaccoes/article/view/11810/9022

OECD. (2014). TALIS $2013 \quad$ Technical Report. Retrieved from http://www.oecd.org/education/school/TALIS-technical-report-2013.pdf

OECD. (2016). TALIS 2018 - Inquérito internacional sobre ensino e aprendizagem. Retrieved from http://www.dgeec.mec.pt/np4/108/\%7B \$clientServletPath\%7D/?newsId=162\&fileName=TALIS_ 2018_brochura_PT1.pdf

Patrão, I., Pinto, C., \& Santos-Rita, J. (2012). Bem-estar e Estratégias de Gestão das Exigências em Professores Portugueses dos Diferentes Níveis de Ensino. Actas Do $12^{\circ}$ Colóquio de Psicologia e Educação, 575-585. Retrieved from http://repositorio.ispa.pt/bitstream/10400.12/1615/1/CIPE 2012 575-585.pdf

Patrão, I., Rita, J., \& Maroco, J. (2012). Avaliação do Burnout em Professores: Contributo para o estudo de adaptação do CBP-R. Psychology, Community \& Health, 1(2), 179-188. https://doi.org/10.5964/pch.v1i2.29

Pereira, A. (2013). Motivação na aprendizagem e no ensino. In Climepsi Editores (Ed.), Psicologia da Educação: Teoria, investigação e aplicação. Envolvimento dos alunos na escola (pp. 445-493). Lisboa.

Schleicher, A. (2018). Valuing our Teachers and Raising their Status: How communities can help (International Summit on the Teaching Profession). OECD Publishing. https://doi.org/10.1787/9789264292697-en

UNESCO. (2017). Global Education Monitoring Report 2017/18 - Accountability in Education: Meeting our commitments. Paris. Retrieved from http://unesdoc.unesco.org/images/0025/002593/259338e.pdf

Varela, R. C., della Santa, R., Silveira, H., Coimbra de Matos, A., Rolo, D., Areosa, J., \& Leher, R. (2018). Inquérito Nacional sobre as Condições de Vida e Trabalho na Educação em Portugal ( INCVTE ). Jornal $d a$ FENPROF. Lisboa. Retrieved from https://www.fenprof.pt/?aba=39\&cat=667

Veiga, F. H. (2013). Psicologia da Educação - Teoria, Investigação e Aplicação: Envolvimento dos Alunos na Escola. (Climepsi Editores, Ed.). Lisboa. 